\title{
Forum
}

\section{On forgiving oneself: A reply to Snow}

\author{
PAUL M. HUGHES \\ Department of Humanities, The University of Michigan-Dearborn, Dearborn, MI \\ 48128-3643, USA
}

In "Self-forgiveness" Nancy Snow argues that forgiving oneself for wronging or harming others can (1) restore the wrongdoer to full moral agency, (2) shed light on interpersonal forgiveness, and (3) provide a second-best alternative to full interpersonal forgiveness. Snow's effort brings into focus a much neglected moral phenomenon, and clarifies dimensions of it. Still, selfforgiveness remains a mystery. In the spirit of furthering our understanding of this moral concept, I offer the following reflections on the nature of selfforgiving.

Snow tells us that self-forgiveness is a process that "restores our capability to carry on as functioning agents even after we have committed wrongs or harmed others." 2 This conception of self-forgiveness as "self-rehabilitation" or inner healing presupposes that wrongdoers care enough about the wrong or harm they have caused to be in some way impaired by having done it. ${ }^{3}$ This assumption, however, unduly restricts the scope of self-forgiveness, obscuring the fact that wronging or harming others in a way that is psychologically debilitating to the wrongdoer is the exception rather than the rule. Many of the wrongs we commit are not typically so grave as to cause us significant distress, even when they cause unhappiness to their victims. Moreover, the victim of harm or wrong may be the self, in which case selfforgiveness may be purely self-regarding. If these remarks are right, then self-forgiving as restorative of moral agency may not be the paradigm case of self-foregiveness. Instead, self-forgiveness may more typically be intrapersonal (and have nothing to do with anyone else), occur in cases of wrongdoing or harm that are not serious, and fail to occur even when full interpersonal forgiveness $h$ as been achieved. Let me elaborate on these points.

You might wrong or harm another person, and feel the need to forgive yourself for having done so. This is the case Snow takes as the model for her analysis. But a commonplace is that people harm or wrong themselves, and they sometimes claim to forgive themselves self-inflicted disappointments, wrongs, or harms. Such remarks as, "I was very angry with myself for not even trying to get into medical school," or "I am disappointed with myself 
for having violated my principles," are usual, and they suggest the familar experience of sometimes being your own worst enemy. The view that selfforgiveness is a process of self-healing might be extended to cover this type of case, but only if the self-inflicted harm or wrong is serious enough to cause the psychic damage required by that model. Some self-directed harms are of this magnitude; however, the innumerable less significant self-inflicted wrongs of which we are capable are not. Surely such mundane wrongs or harms are self-forgivable.

Moreover, conceiving self-forgiveness as a process of restoration ignores the fact that people frequently forgive one another minor inconveniences, slights, or offenses. Rather than suppose forgiveness in such cases involves a process of emotional, attitudinal, or characterological transformation, a more plausible supposition is that it (and thus self-forgiveness) is sometimes simply an act. Just as forgiving a minor transgression might be accomplished by the performative speech act, "I forgive you," so too I might forgive myself for having harmed either another person or myself in a minor way by saying (perhaps only to myself), "Oh well, I blew it. I'll have to be more careful next time." Something of the sort will frequently suffice to accomplish selfforgiveness.

Even if self-forgiveness is sometimes a process, Snow is silent about what that process involves. But this lacuna is critical, for whether self-forgiving is moral depends on what it involves. If self-forgiving requires neutralizing a negative emotion directed toward yourself, then the negative emotions that count, the manner in which they are overcome, and the reasons for renouncing them all bear on its moral status. Are the negative emotions to be neutralized forms of anger, or do sadness, disappointment, or depression count as well? Does self-forgiving involve abandoning beliefs about myself, such as that I am a bad or even horrible person for having done wrong or caused harm? What is the difference between self-forgiving and closely related phenomena such as condoning and pardoning? These questions require answers if we are to have anything like a comprehensive theory of self-forgiveness. ${ }^{4}$

Though self-forgiveness is sometimes a "second best" outcome in cases where full interpersonal forgiveness is not to be had, this does not imply that full interpersonal forgiveness requires self-forgiveness. Again, cases of unserious wrongs or harms illustrate this point. If I am jogging beside the foot path you are strolling along and I step into a puddle and splash mud onto your new shoes, I might stop and apologize, asking you to forgive my clumsiness, and you might do so. Full interpersonal forgiveness in this case hardly requires that I forgive myself, especially if I do not feel at all guilty, ashamed, or embarrassed for having wronged or harmed you. To suppose that no harm occurs in such cases would be a mistake, since even inconvenience can constitute harm; and to experience strong negative emotions directed toward 
oneself on occasions of minor wrongdoing or harming such as this would be odd (perhaps evidence of neurosis). Consequently, though wrongdoers cannot by themselves effect full interpersonal forgiveness, and thus self-forgiveness will sometimes be the best they can hope for, not all cases of full interpersonal forgiveness require self-forgiveness. Sometimes (again) full interpersonal forgiveness may be effected by the victim's assertion, "I forgive you."

I close with several remarks on the relationship between self-forgiveness and cognate concepts such as condoning and pardoning, and the idea that some wrongs or harms are unforgivable.

In attempting to delimit the notion of self-forgiveness, Snow claims that "self-forgiveness should not condone moral failings," and that "to forgive yourself is to fully accept that you have erred, to repent, and to pardon yourself." These claims obfuscate rather than clarify self-forgiveness, for the ambiguity in the first leaves us wondering whether self-forgiving is sometimes nothing more than condoning our own wrongdoing, or whether instead self-forgiveness cannot (by definition) be condonation. If the first interpretation is correct (and the assertion that self-forgiveness should not condone moral failings presupposes that it could), then we need an account of the difference between condoning and self-forgiving so that we can know when self-forgiving is tantamount to condoning. This knowledge is crucial for avoiding self-condoning, which is a vice, not a virtue.

The second claim confounds pardoning with forgiving, but these are two quite different moral phenomena. Pardoning implies releasing a wrongdoer from the consequences of culpable wrongdoing or harming. It is therefore incompatible with punishing the wrongdoer, though compatible with (and sometimes tantamount to) condoning wrong. Forgiving, by contrast, while compatible with punishing a wrongdoer, is incompatible with condoning wrongdoing.

Finally, self-forgiveness is said to be a second-best option when full interpersonal forgiveness is not or cannot be accomplished. Sometimes unsympathetic victims refuse to accept apology and forgive wrongdoers, and sometimes the wrong or harm committed is so heinous as to be beyond a wrongdoer's ability to atone for it. Snow correctly emphasizes that self-forgiveness may be in order in such cases, for the simple reason that we must get on with our lives. But what about especially vile wrongs or harms? Is self-forgiveness a second-best alternative to full interpersonal forgiveness in these cases? The relationship between forgiveness and despicable wrongs may be more complicated than Snow's view supposes. Are especially grievous offenses beyond forgiveness because wrongdoers are incapable of atoning for them, or are they intrinsically unforgivable? If they are incapable of being atoned for, what incapacity is this? Psychological? Financial? Or is it 
that some wrongs or harms are so enormous that the wrongdoer has no one to appeal to (except God) for forgiveness? Then forgiveness would be impossible not because of any incapacity of the wrongdoer, but because no other person is in a position to extend forgiveness to him or her. Nazi prison guards who participated in the torture deaths of hundreds of Jews have no one to ask for forgiveness, since no one person or group has the moral standing to forgive crimes of such enormity. Moreover, some wrongs are unforgivable not because of anyone's inability to atone for or to forgive them, but because they are by their nature beyond the pale of forgiveness. The various forms of betrayal are sometimes thought to be paradigm cases of such wrongs:

Worse than murder, worse than incest, betrayal of country invites universal scorn. Betrayal of lover is regarded by many as an irremediable breach. For the religious, betrayal of God is the supreme vice. The specific forms of betrayal ... all reek with evil. ${ }^{6}$

And they reek with evil because they cannot be made good, no matter what anyone does to atone for or forgive them. If some wrongs or harms are beyond forgiveness in these ways, then it follows that they cannot be selfforgiven either.

Forgiving yourself sometimes requires neutralizing a self-directed negative emotion caused by having wronged someone else. But there is more to the story of self-forgiveness than this.

\section{Notes}

1. Nancy Snow, "Self-forgiveness," The Journal of Value Inquiry 27 (1993): 75-80.

2. Ibid., p. 75 .

3. This is implicit in Snow's admission that "After a serious moral failure, we must, to regain our bearings as functioning moral agents, be able to recognize and accept our imperfections and forgive ourselves for having them and for sometimes acting wrongly." Ibid., p. 76.

4. For more on these issues see my "What is involved in forgiving?", The Journal of Value Inquiry 27 (1993): 331-340.

5. Snow, "Self-forgiveness," p. 76.

6. George P. Fletcher, Loyalty (New York: Oxford University Press, 1993), p. 41. 